\title{
Hemispheric Asymmetry in the Ventilated Thermocline of the Tropical Pacific 0
}

\author{
L. B. KUNTZ AND D. P. SCHRAG \\ Department of Earth and Planetary Sciences, Harvard University, Cambridge, Massachusetts
}

(Manuscript received 11 October 2017, in final form 7 December 2017)

\begin{abstract}
To understand sources of variability in the eastern equatorial Pacific, a region integral to modulating global temperatures, the waters upwelling from the Equatorial Undercurrent (EUC) are characterized. Past work is updated using temperature and salinity measurements from the Argo array and current measurements from Tropical Atmosphere Ocean (TAO) buoys. A larger hemispheric asymmetry is found in the water mass contribution through the ventilated thermocline to the EUC than previously reported, with $80 \%-90 \%$ of waters in the western Pacific originating from the Southern Hemisphere. South Pacific subtropical waters are the dominant source feeding the EUC, although in the central equatorial Pacific upper layers of the EUC experience freshening due to the addition of North Pacific waters. Anomalous volume transport, advection of anomalous waters, and shifts in hemispheric contributions contribute to variability in the EUC. These results suggest that variability in the EUC caused by anomalies in the South Pacific ventilated thermocline can explain variability in the eastern equatorial Pacific.
\end{abstract}

\section{Introduction}

The upper thermocline of the tropical Pacific is a crossroads of waters from both hemispheres. In the western equatorial Pacific, subsurface waters feed into the Equatorial Undercurrent (EUC), which transports the waters eastward until they upwell off the coast of Peru. These upwelling waters set the state of the eastern equatorial Pacific, a region critical to modulating global surface temperatures (Kosaka and Xie 2013). A warm eastern Pacific is tied to higher temperatures around the world, and the reverse is the case for a cold eastern Pacific. Variability in the composition and quantity of waters transported by the EUC can alter the state of the eastern Pacific. Understanding the circulation pathways in the tropical Pacific is integral to forecasting the state of the eastern equatorial Pacific and its impact on global surface temperatures.

Initial studies characterized the composition of EUC waters using geochemical properties as tracers from ship

Supplemental information related to this paper is available at the Journals Online website: https://doi.org/10.1175/JCLID-17-0686.s1.

Corresponding author: Lauren Kuntz, lkuntz@fas.harvard.edu transects and defining different water mass regions by average chemical compositions (Toole et al. 1988; Tsuchiya et al. 1989). Assuming negligible diapycnal mixing, these studies quantified the contribution of each region to EUC transport by requiring the mass-weighted geochemical flux to explain the EUC composition. The results suggested a 2:1 contribution of Southern to Northern Hemisphere waters (Tsuchiya et al. 1989). However, this method was sensitive to the location used to define the different water regions, did not trace subsurface waters to their origin at the surface, and could not capture the dynamical variability of the system.

Later studies identified a subtropical origin of waters entering the tropical Pacific through subtropical cells (STCs). The theory of ventilated thermocline transport provided a simplified analytical framework to explain the STCs' circulation pathway, positing that waters subducted in the subtropics propagate along isopycnals to the equatorial Pacific, feeding into the EUC and upwelling in the eastern Pacific (Luyten et al. 1983; Pedlosky 1987; McCreary and Lu 1994). Chemical tracers supported this circulation pathway (Broecker et al. 1985, 1995; Druffel 1987; Fine et al. 1987). Additional work by Johnson and McPhaden (1999) sought to refine and quantify different transport pathways of the STCs using CTD data over a 33-yr period to create a 
climatology. This work noted a direct route between the subtropics and equator in the Southern Hemisphere, and affirmed the dominance of southern source waters in EUC transport found by Tsuchiya et al. (1989). General circulation models also support the dominance of the southern STCs (Izumo et al. 2002; Rodgers et al. 2003; Fukumori et al. 2004; Goodman et al. 2005; Grenier et al. 2011; Qin et al. 2015).

Both changes in the transport profile or volume and the advection of salinity compensated temperature anomalies within the ventilated thermocline could cause variability within the EUC and eastern equatorial Pacific (Kleeman et al. 1999; Gu and Philander 1997). Evidence for coherent propagation of temperature anomalies has remained elusive (Schneider et al. 1999a,b; Hazeleger et al. 2001; Kolodziejczyk and Gaillard 2012). Observational studies have supported decadal variability in transport volume, with decreased transport toward the end of the twentieth century corresponding to increasing temperatures in the Niño-3.4 region (McPhaden and Zhang 2002, 2004; Zhang and McPhaden 2006). These results are consistent with subtropical regulation of the eastern equatorial Pacific.

Here, we use data with better temporal and spatial resolution than in past studies to gain further observational insight into EUC source waters and variability. In the past, limited observations have restricted analyses of transport pathways. We combine temperature and salinity data from the Argo array with equatorial currents from the Tropical Atmosphere Ocean (TAO) array to provide a more complete picture of the climatology and variability of water properties throughout the tropical Pacific. We use these data to reexamine ventilated thermocline transport of subtropical waters to the tropics, and the hemispheric asymmetry of contributions to the EUC.

\section{Data and methods}

We combine data from the Roemmich-Gilson Argo climatology (Roemmich and Gilson 2009, 2017) with the TAO array (TAO Project Office 2000). The Argo climatology contains temperature and salinity, which we use to calculate potential density anomaly $\sigma_{\theta}\left(\mathrm{kg} \mathrm{m}^{-3}\right)$. Data from the TAO array's acoustic Doppler current profilers (ADCPs) provide subsurface velocity profiles on monthly time scales for five longitudinal locations $\left(147^{\circ} \mathrm{E}, 165^{\circ} \mathrm{E}, 170^{\circ} \mathrm{W}, 140^{\circ} \mathrm{W}\right.$, and $\left.110^{\circ} \mathrm{W}\right)$. We use these data over the time period of the Argo climatology (2004-15) to calculate the climatological depth of the EUC. As some of the ADCP data are missing, we first calculate the monthly climatology of zonal current with depth at each longitudinal location before combining these into an annual average. We define the upper and lower bounds of the EUC to be the depths bounding $90 \%$ of the subsurface eastward transport. In conjunction with the Argo data, these bounds are used to define velocityweighted (and thus transport volume weighted) averages of EUC properties. Bounds and velocity-weighted properties are not specified for the profile along $147^{\circ} \mathrm{E}$, as the EUC extends deeper than the ADCP data.

Following the method used in Tsuchiya et al. (1989), we quantify the relative abundance of Northern and Southern Hemisphere waters feeding into the EUC. We define the properties of the subtropical source waters as the climatological average over the water column in the westward, equatorward portion of the subducting zones $\left(30^{\circ}-25^{\circ} \mathrm{S}, 160^{\circ}-110^{\circ} \mathrm{W}\right.$ and $\left.30^{\circ}-35^{\circ} \mathrm{N}, 160^{\circ} \mathrm{E}-160^{\circ} \mathrm{W}\right)$ (Rodgers et al. 2003). Along each isopycnal, the waters at the equator are defined by the fraction of southern subtropical waters required to explain the salinity signal. The fraction of Southern Hemisphere waters is taken as the ratio of the difference between the equatorial and the southern subtropical salinities to the difference between the northern and southern subtropical salinities. Many different regions could be chosen to define profiles for Northern and Southern Hemisphere waters, which could impact the fraction of Southern Hemisphere waters. We have explored this possibility and have found that neither expanding the region nor shifting the region zonally and poleward substantially impacts the results. Moving the defining region equatorward does change the hemispheric properties and fraction of Southern Hemisphere waters, but such a shift moves the region outside of the subduction zone.

To assess the variability of the EUC, we also examine the subsurface properties during an El Niño and La Niña. We use December of 2009 and 2010 respectively, as these are the times during the Argo observing period with the largest El Niño indices that also have ADCP measurements from at least three of the five equatorial buoys. As with the EUC climatology, we examine the relative abundance from the Northern and Southern Hemispheres along isopycnals. When defining the subducted water properties, we do not consider variability in these regions but rather use the average climatology.

\section{Results}

Figure 1 shows zonal cross sections of salinity and potential density in the North and South Pacific. Along a given isopycnal, colder, fresher waters characterize the North Pacific, while warmer, saltier waters compose the South Pacific. In both hemispheres, high salinity regions at the surface in the subtropics subduct and extend westward and equatorward within the ventilated thermocline between $24 \sigma_{\theta}$ and $26 \sigma_{\theta}$. Although there are many pathways water parcels can follow from the tropics 


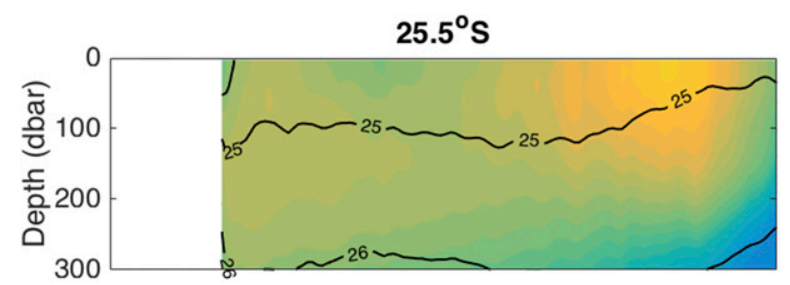

$15.5^{\circ} \mathrm{S}$

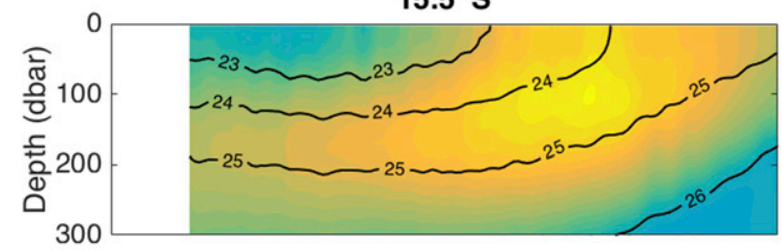

$5.5^{\circ} \mathrm{S}$

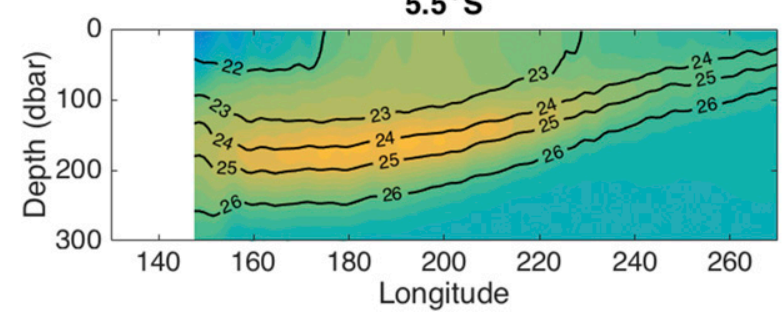

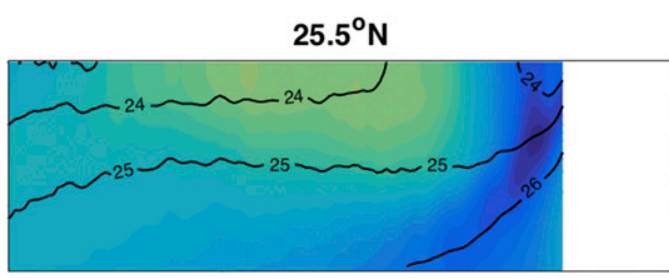

$15.5^{\circ} \mathrm{N}$

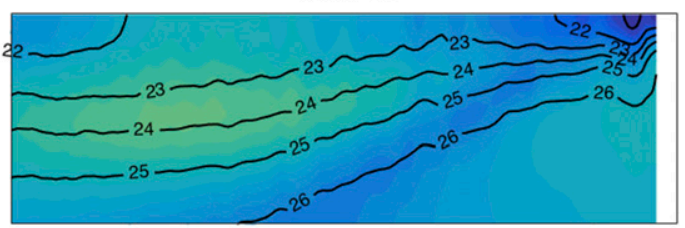

$5.5^{\circ} \mathrm{N}$

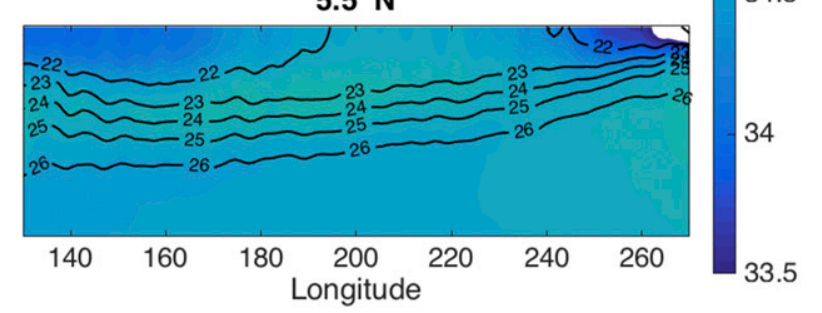

FIG. 1. Zonal cross sections of water composition in the Pacific Ocean. Salinity (psu; color shading) and potential density anomaly ( $\mathrm{kg} \mathrm{m}^{-3}$; contours) from the Argo climatology are shown with depth along three latitudes in the (left) South Pacific and (right) North Pacific. [Depth on the left $y$ axis is shown in decibars (dbar; $\left.1 \mathrm{dbar}=10^{4} \mathrm{~Pa}\right)$.]

to the subtropics, this westward and equatorward extension roughly follows the trajectory particles subducted in the subtropics take to the tropics (Lee et al. 2002). As the salinity high in the South Pacific extends to $5.5^{\circ} \mathrm{S}$, it conserves its magnitude but decreases in thickness as the isopycnal surfaces are compressed together. In contrast, the salinity high in the North Pacific largely dissipates by $5.5^{\circ} \mathrm{N}$.

Figure 2 shows the salinity evolution along the path of ventilated thermocline transport from the subtropics to the western Pacific. The transport path is an approximation of particle trajectories between the subtropics and tropics seen in modeling studies (Lee et al. 2002; Thomas and Fedorov 2017). Relative to the surrounding waters, the salinity maximum within the ventilated thermocline is greater in the South Pacific. Although the maximum is damped as the equator is approached in both hemispheres, the salinity gradient across the ventilated thermocline is nearly gone in the north but a distinct salinity maximum remains in the south. As the equatorial Pacific is approached, the salinity high in the northern branch of the ventilated thermocline is shallower and thinner than that in the southern branch; the northern salinity high is confined between $24 \sigma_{\theta}$ and $25 \sigma_{\theta}$, while the southern high extends to $26 \sigma_{\theta}$.

Along the equator, Fig. 3 depicts the evolution of waters as they travel from depth in the western Pacific toward the surface in the east and Table 1 gives the velocity-weighted average EUC properties. The waters in the west feeding the EUC come from just below the salinity high, at a potential density around $26 \sigma_{\theta}$. As the waters shoal and are swept toward $170^{\circ} \mathrm{W}$, the salinity increases and potential density decreases to $25 \sigma_{\theta}$. Farther eastward, the salinity is diluted and potential density increases again. This dilution corresponds to an increase in the mass flux within the EUC between $170^{\circ}$ and $140^{\circ} \mathrm{W}$, suggesting the addition of lower salinity waters. Over the same region, the relative contribution of Southern Hemisphere waters drops. The contribution of source waters is highly stratified with depth, with the top portion of the EUC displaying a larger portion of northern source waters, while the deeper portion is nearly exclusively fed by the Southern Hemisphere.

Figure 4 explores the variability of EUC transport, providing a snapshot of hemispheric contribution and transport strength during El Niño and La Niña. During the El Niño event, the stratification of the southern contribution with depth remains nearly constant across the EUC. A greater portion of the EUC transport is composed of light, upper-layer waters. In contrast, during La Niña, the upper bound of the EUC remains near $24 \sigma_{\theta}$ and the transport is shifted to deeper layers composed mainly of Southern Hemisphere waters. The stratification of the hemispheric contribution with depth is enhanced, with the upper layers exhibiting more 

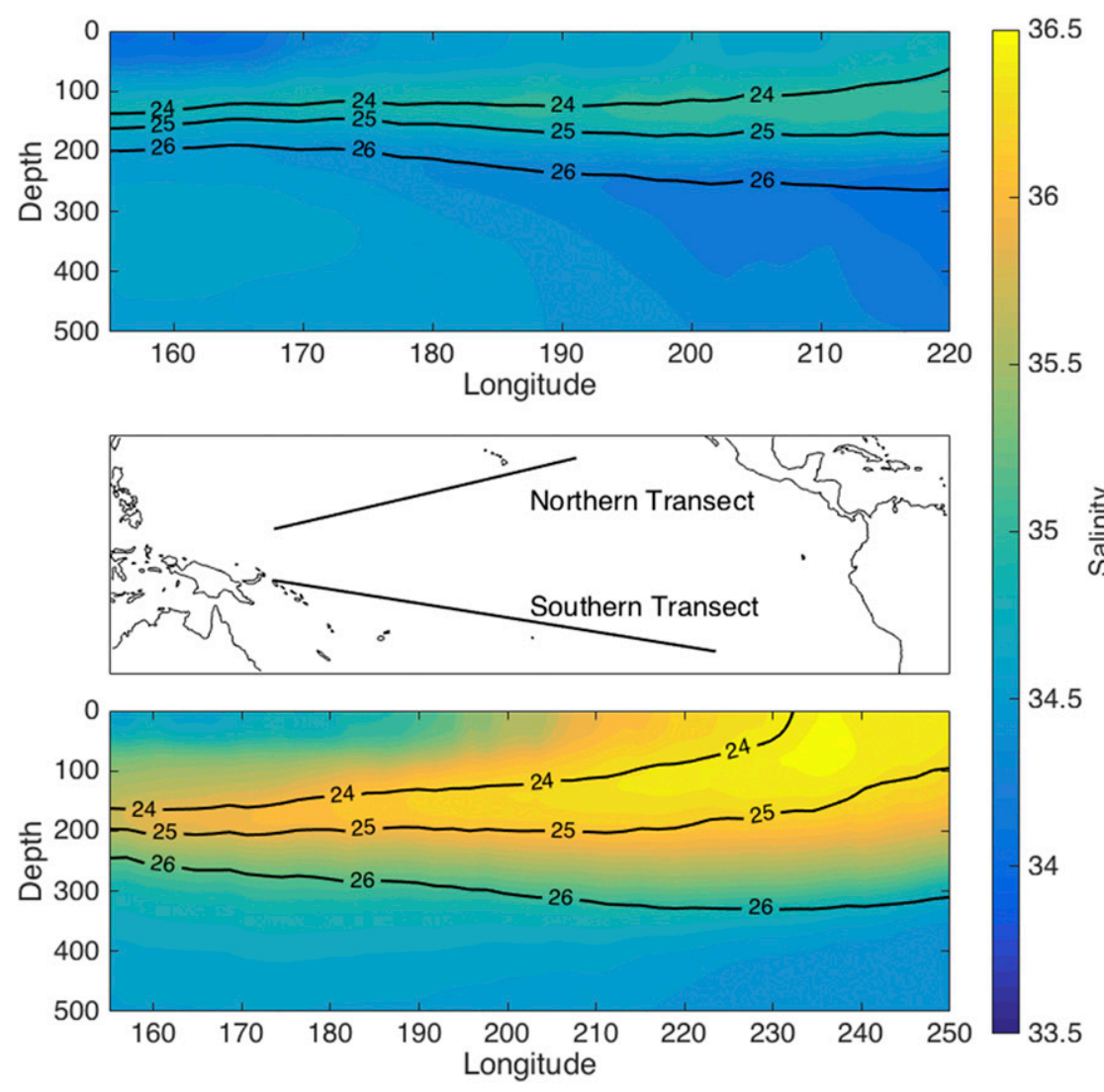

FIG. 2. Cross section along the path of ventilated thermocline transport in the (top) North Pacific and (bottom) South Pacific. Salinity (psu; color shading) and potential density anomaly ( $\mathrm{kg} \mathrm{m}^{-3}$; contours) from the Argo climatology are shown along the transects, and (middle) the geographic extent of the transects is depicted. (Depth on the left $y$ axis is shown in decibars.)

freshening during La Niña. Neutral conditions in the eastern equatorial Pacific are roughly an average of the two extremes. Additional monthly snapshots of EUC variability can be found in the supplemental material.

\section{Discussion}

The hydrography of the ventilated thermocline highlights the complicated transport pathway between the subtropics and tropics with mixing and dilution occurring throughout. Particularly in the North Pacific, the subducted salinity high is dissipated as it propagates toward the western equatorial Pacific. Consistent with modeling conclusions (Rodgers et al. 2000), the weaker density stratification in the North Pacific suggests that greater diapycnal mixing in this hemisphere contributes to the larger dissipation of the subducted salinity high.

The signal evolution along the ventilated thermocline path requires careful interpretation of the hemispheric contribution metric. The metric treats the ventilated thermocline as a pipe along isopycnals and ignores dilution, which can lead to unphysical values. For instance, at depth the southern contribution exceeds 1 . Although this highlights the dominance of southern waters with mixing occurring along and across isopycnals, it also raises the possibility of additional water sources or waters from depth contributing high salinity waters. Using different locations to define the characteristics of northern and southern source waters will result in different hemispheric contributions along the equator, but this does not change the overall picture. By defining the source waters within the subducting region, the metric becomes a measure of the strength of the hemispheric subtropical signals that coherently reach the equator.

A strong asymmetry exists between northern and southern subtropical waters within the EUC, both across the basin and with depth. A freshening occurs in the central Pacific that aligns with an increase in flux of the EUC. This suggests that the evolution is due to the addition of North Pacific waters as opposed to just mixing and entrainment. As the TAO array only captures the equatorial transect, it is possible that the EUC as a whole 


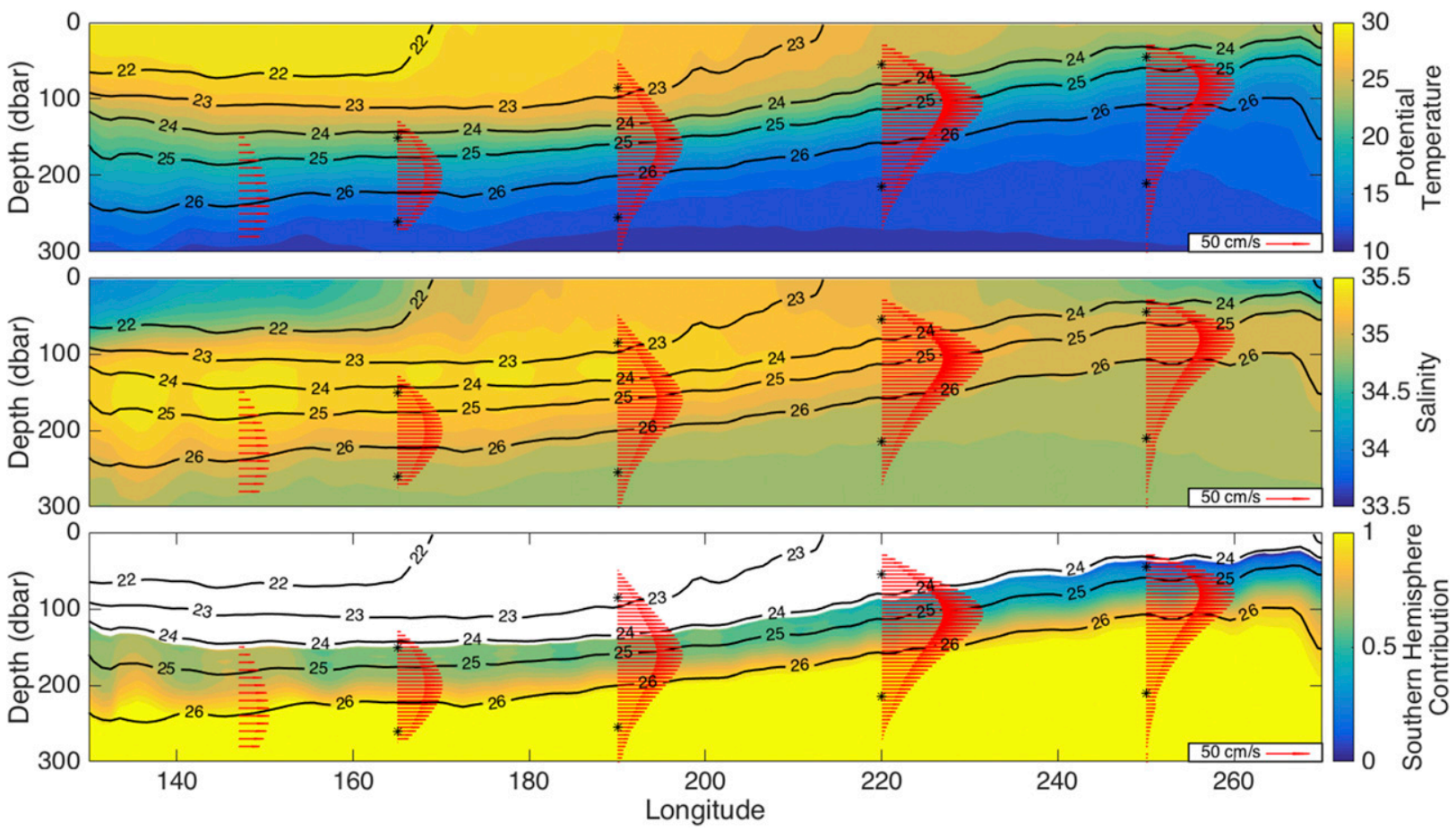

FIG. 3. Equatorial cross section and the EUC. (top) Potential temperature $\left({ }^{\circ} \mathrm{C}\right)$, (middle) salinity from the Argo climatology (psu) and (bottom) the relative contributions of southern subtropical source waters are shown along the equator of the Pacific. Potential density anomaly $\left(\mathrm{kg} \mathrm{m}^{-3}\right)$ contours (black) are plotted for reference, as are the climatological zonal velocities in the EUC from the TAO buoys (red vectors). Black asterisks mark the upper and lower bounds of the EUC that contain $90 \%$ of the water mass transport.

does not undergo this evolution. If the latitudinal location of the EUC's core varies as it traverses the basin, part of the signal would come from sampling the center of the current at some buoys while measuring the edge of the current at others. However, Fine et al. (1987) noted a similar increase in tritium, a tracer of North Pacific subtropical waters, in the central Pacific EUC affirming the view of along path addition of North Pacific waters. This freshening is restricted to the upper layers of the EUC, enhancing the stratification of hemispheric contribution with depth. As the upper levels will upwell first, the central equatorial Pacific should reflect more Northern Hemisphere influence than the eastern equatorial Pacific.

Past studies have pointed toward both the intertropical convergence zone (ITCZ) and the Indonesian Throughflow
(ITF) as an explanation for the dominance of South Pacific source waters in the EUC. The upwelling induced by the ITCZ creates a potential vorticity barrier in the North Pacific, forcing waters in the ventilated thermocline to take a serpentine route and inhibiting flow (Lu and McCreary 1995; Johnson and McPhaden 1999). Furthermore, the ITF drains waters from the North Pacific ventilated thermocline into the Indian Ocean, reducing the flux of Northern Hemisphere subtropical waters to the western Pacific. Previous studies have shown how the strength of the ITF contributes to the relative contribution of northern and southern waters in the EUC, with the hemispheric asymmetry scaling with ITF flux (Rodgers et al. 1999; Lee et al. 2002).

TABLE 1. Velocity-weighted average properties within the EUC. Average salinity, temperature, and Southern Hemisphere contribution are given for the Argo climatology using the climatological location and velocity of EUC from the TAO data.

\begin{tabular}{lcccc}
\hline \hline & \multicolumn{3}{c}{ Longitude } \\
\cline { 2 - 5 } & $165^{\circ} \mathrm{E}$ & $170^{\circ} \mathrm{W}$ & $140^{\circ} \mathrm{W}$ & $310^{\circ} \mathrm{W}$ \\
\hline Salinity $(\mathrm{psu})$ & 35.2 & 35.2 & 35.1 & 35.0 \\
Potential temperature $\left({ }^{\circ} \mathrm{C}\right)$ & 17.3 & 19.7 & 18.7 & 15.8 \\
Southern Hemisphere contribution & 0.84 & 0.83 & 0.73 & 0.78 \\
\hline
\end{tabular}



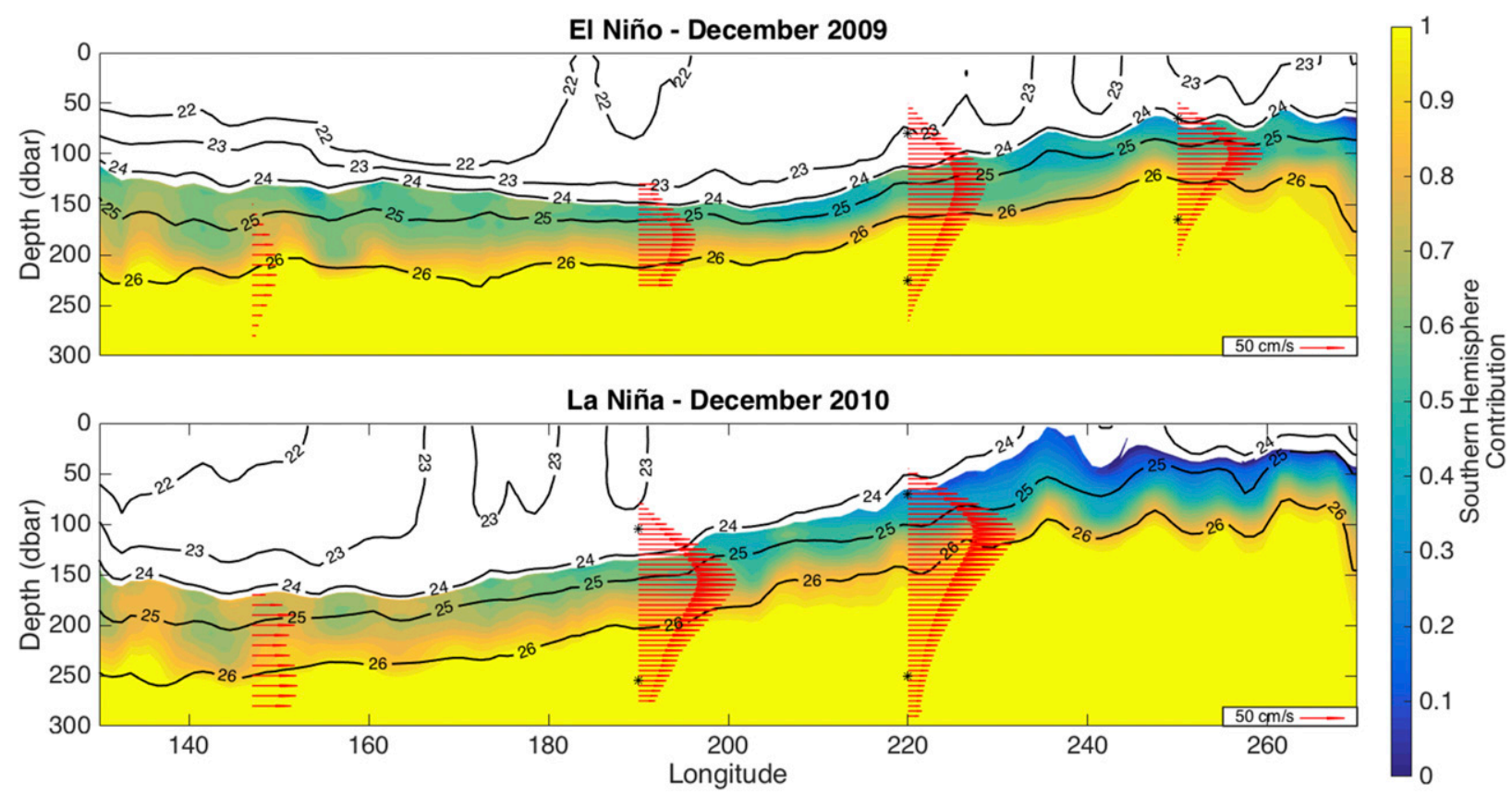

FIG. 4. Equatorial cross section during (top) an El Niño event in December 2009 and (bottom) a La Niña event in December 2010. The relative contributions of southern subtropical source waters are shown along the equator of the Pacific. Potential density anomaly $\left(\mathrm{kg} \mathrm{m}^{-3}\right)$ contours (black) are plotted for reference, as are the zonal velocities in the EUC from the TAO buoys (red vectors). Black asterisks mark the upper and lower bounds of the EUC that contain $90 \%$ of the water mass transport.

The ITCZ and ITF, however, cannot explain why additional northern waters are incorporated into the EUC in the central Pacific or why the hemispheric contribution is stratified with depth. Northern Hemisphere water freshening in the interior could be due to the asymmetry in surface Ekman flux in the central Pacific that favors transport into the Northern Hemisphere (Johnson et al. 2001), driving more subsurface convergence from the Northern Hemisphere into the EUC. Alternatively, the presence of tropical cells mixing low salinity, off-equatorial, surface water into the subsurface could also explain the freshening. The stratification of hemispheric contribution with depth could arise from the asymmetry between the North and South Subsurface Countercurrents (NSCC and SSCC, respectively). The NSCC extends to lighter isopycnal levels and is stronger than the SSCC, placing a greater restriction on interior transport from the Northern Hemisphere into the EUC (Johnson et al. 2002).

Variability in water composition during ENSO events arises from both circulation anomalies and advection of waters with anomalous properties. During the $2009 \mathrm{El}$ Niño, the hemispheric contribution shifts toward northern source waters as a result of a change in transport favoring the upper layers of the EUC. In contrast, during La Niña, the stratification of hemispheric contributions is enhanced and transport shifts to deeper layers. Both the addition of colder, northern waters in the upper layers as well as greater transport at depth cools the EUC. By shifting the EUC water composition, this variability could also impact the nutrient transport, biogeochemistry, and productivity in the eastern equatorial Pacific.

Similar mechanisms of variability should explain changes in EUC transport on longer time scales; however, the dominance of South Pacific waters feeding the EUC suggests that the southern branch of the ventilated thermocline should display greater control over variations. A number of modeling studies have affirmed a southern source of variability to the EUC and eastern equatorial Pacific (Giese et al. 2002; Farneti et al. 2014; Thomas and Fedorov 2017); however, the mechanism of variability remains contested. In agreement with observations (McPhaden and Zhang 2002, 2004), Farneti et al. (2014) suggested that variability of volume transport in the southern STC explained variability in the equatorial circulation. This contrasts the view of the ventilated thermocline from Gu and Philander's (1997) analytical model, which relies on transport of temperature anomalies. Past observational studies were unable to find evidence of anomaly transport (Schneider et al. 1999a,b; Hazeleger et al. 2001) but focused on anomalies within the North Pacific as the majority of subsurface data was confined to the Northern Hemisphere prior to the Argo array. More recent modeling work has suggested 
that temperature anomaly transport from the South $\mathrm{Pa}$ cific could explain the equatorial variability (Giese et al. 2002; Thomas and Fedorov 2017). Although the question remains of whether anomalous transport or transport of temperature anomalies drive variability, the dominance of southern waters in the EUC suggests that the South Pacific rather than the North Pacific could hold evidence for influencing longer time scale EUC variability.

\section{Conclusions}

Using data from both the Argo float array and TAO/ TRITON buoys we conduct an observational analysis of EUC source waters. Affirming past studies, we find that the South Pacific is the dominant source of subtropical waters that feed into the EUC, although addition of northern waters freshens the upper layers in the central Pacific. This large hemispheric asymmetry in the equatorial ventilated thermocline is likely due to a combination of greater diapycnal mixing in the North Pacific, the presence of the ITCZ and ITF, and the asymmetry in Ekman transport. Interannual variability in EUC transport arises from anomalous advection, shifts in the hemispheric contribution, and advection of anomalies. The dominance of the South Pacific subtropical waters feeding the EUC suggests that to understand the variability in the eastern equatorial Pacific it is necessary to look to the variability and anomalous transport of waters along the ventilated thermocline in the Southern Hemisphere.

Acknowledgments. This material is based upon work supported by a National Science Foundation Graduate Research Fellowship (Grant DGE1144152) to LBK and a Star Family Challenge Grant to DPS. Data from the Tropical Atmosphere Ocean Project came from the TAO Project Office of NOAA/PMEL.

\section{REFERENCES}

Broecker, W. S., T.-H. Peng, G. Ostlund, and M. Stuiver, 1985: The distribution of bomb radiocarbon in the ocean. J. Geophys. Res., 90, 6953-6970, https://doi.org/10.1029/JC090iC04p06953.

- S. Sutherland, W. Smethie, T.-H. Peng, and G. Ostlund, 1995: Oceanic radiocarbon: Separation of the natural and bomb components. Global Biogeochem. Cycles, 9, 263-288, https:// doi.org/10.1029/95GB00208.

Druffel, E. R. M., 1987: Bomb radiocarbon in the Pacific: Annual and seasonal timescale variations. J. Mar. Res., 45, 667-698, https:// doi.org/10.1357/002224087788326876.

Farneti, R., S. Dwivedi, F. Kucharski, F. Molteni, and S. M. Griffies, 2014: On Pacific subtropical cell variability over the second half of the twentieth century. J. Climate, 27, 7102-7112, https://doi.org/ 10.1175/JCLI-D-13-00707.1.

Fine, R. A., W. H. Peterson, and H. G. Ostlund, 1987: The penetration of tritium into the tropical Pacific. J. Phys. Oceanogr., 17, 553-564, https://doi.org/10.1175/1520-0485(1987)017<0553: TPOTIT $>2.0 . \mathrm{CO} ; 2$
Fukumori, I., T. Lee, B. Cheng, and D. Menemenlis, 2004: The origin, pathway, and destination of Nino-3 water estimated by a simulated passive tracer and its adjoint. J. Phys. Oceanogr., 34, 582-604, https://doi.org/10.1175/2515.1.

Giese, B. S., S. C. Urizar, and N. S. Fučkar, 2002: Southern Hemisphere origins of the 1976 climate shift. Geophys. Res. Lett., 29, 1014, https://doi.org/10.1029/2001GL013268.

Goodman, P. J., W. Hazeleger, P. de Vries, and M. Cane, 2005: Pathways into the Pacific Equatorial Undercurrent: A trajectory analysis. J. Phys. Oceanogr., 35, 2134-2151, https://doi.org/ 10.1175/JPO2825.1.

Grenier, M., S. Cravatte, B. Blanke, C. Menkes, A. Koch-Larrouy, F. Durand, A. Melet, and C. Jeandel, 2011: From the western boundary currents to the Pacific Equatorial Undercurrent: Modeled pathways and water mass evolution. J. Geophys. Res., 116, C12044, https://doi.org/10.1029/2011JC007477.

Gu, D., and S. G. H. Philander, 1997: Interdecadal climate fluctuations that depend on exchanges between the tropics and extratropics. Science, 275, 805-807, https://doi.org/ 10.1126/science.275.5301.805.

Hazeleger, W., M. Visbeck, M. Cane, A. Karspeck, and N. Naik, 2001: Decadal upper ocean temperature variability in the tropical Pacific. J. Geophys. Res., 106, 8971-8988, https://doi.org/10.1029/ 2000JC000536.

Izumo, T., J. Picaut, and B. Blanke, 2002: Tropical pathways, equatorial undercurrent variability and the 1998 La Nina. Geophys. Res. Lett., 29, 2080, https://doi.org/10.1029/2002GL015073.

Johnson, G. C., and M. J. McPhaden, 1999: Interior pycnocline flow from the subtropical to equatorial Pacific Ocean. J. Phys. Oceanogr., 29, 3073-3089, https://doi.org/10.1175/1520-0485 (1999)029<3073:IPFFTS >2.0.CO;2.

, - _ and E. Firing, 2001: Equatorial Pacific Ocean horizontal velocity, divergence, and upwelling. J. Phys. Oceanogr., 31, 839-849, https://doi.org/10.1175/1520-0485(2001)031<0839: EPOHVD $>2.0 . \mathrm{CO} ; 2$.

, B. M. Sloyan, W. S. Kessler, and K. E. McTaggart, 2002: Direct measurements of upper ocean currents and water properties across the tropical Pacific during the 1990s. Prog. Oceanogr., 52, 31-61, https://doi.org/10.1016/S0079-6611(02)00021-6.

Kleeman, R., J. P. McCreary, and B. A. Klinger, 1999: A mechanism for generating ENSO decadal variability. Geophys. Res. Lett., 26, 1743-1746, https://doi.org/10.1029/1999GL900352.

Kolodziejczyk, N., and F. Gaillard, 2012: Observation of spiciness interannual variability in the Pacific pycnocline. J. Geophys. Res., 117, C12018, https://doi.org/10.1029/2012JC008365.

Kosaka, Y., and S. P. Xie, 2013: Recent global-warming hiatus tied to equatorial Pacific surface cooling. Nature, 501, 403-407, https:// doi.org/10.1038/nature12534.

Lee, T., I. Fukumori, D. Menemenlis, Z. Xing, and L. L. Fu, 2002: Effects of the Indonesian Throughflow on the Pacific and Indian Oceans. J. Phys. Oceanogr., 32, 1404-1429, https://doi.org/ 10.1175/1520-0485(2002)032<1404:EOTITO>2.0.CO;2.

Lu, P., and J. P. McCreary, 1995: Influence of the ITCZ on the flow of thermocline water from the subtropical to the equatorial Pacific Ocean. J. Phys. Oceanogr., 25, 3076-3088, https://doi.org/10.1175/ 1520-0485(1995)025<3076:IOTIOT>2.0.CO;2.

Luyten, J. R., J. Pedlosky, and H. Strommel, 1983: The ventilated thermocline. J. Phys. Oceanogr., 13, 292-309, https://doi.org/ 10.1175/1520-0485(1983)013<0292:TVT>2.0.CO;2.

McCreary, J. P., and P. Lu, 1994: Interaction between the subtropical and equatorial ocean circulations: The subtropical cell. J. Phys. Oceanogr., 24, 466-497, https://doi.org/10.1175/ 1520-0485(1994)024<0466:IBTSAE > 2.0.CO;2. 
McPhaden, M. J., and D. Zhang, 2002: Slowdown of the meridional overturning circulation in the upper Pacific Ocean. Nature, 415, 603-608, https://doi.org/10.1038/415603a.

— phys. Res. Lett., 31, L18301, https://doi.org/10.1029/ 2004 GL020727.

Pedlosky, J., 1987: An inertial theory of the Equatorial Undercurrent. J. Phys. Oceanogr., 17, 1978-1985, https://doi.org/ 10.1175/1520-0485(1987)017<1978:AITOTE>2.0.CO;2.

Qin, X., A. S. Gupta, and E. van Sebille, 2015: Variability in the origins and pathways of Pacific Equatorial Undercurrent water. J. Geophys. Res., 120, 3113-3128, https://doi.org/10.1002/ 2014JC010549.

Rodgers, K. B., M. A. Cane, N. H. Naik, and D. P. Schrag, 1999: The role of the Indonesian Throughflow in equatorial Pacific thermocline ventilation. J. Geophys. Res., 104, 20 551-20 570, https://doi.org/10.1029/1998JC900094.

— D. P. Schrag, M. A. Cane, and N. H. Naik, 2000: The bomb ${ }^{14} \mathrm{C}$ transient in the Pacific Ocean. J. Geophys. Res., 105, 8489-8512, https://doi.org/10.1029/1999JC900228.

_- B. Blanke, G. Madec, O. Aumont, P. Ciais, and J.-C. Dutay, 2003: Extratropical sources of equatorial Pacific upwelling in an OGCM. Geophys. Res. Lett., 30, 1084, https://doi.org/ 10.1029/2002GL016003.

Roemmich, D., and J. Gilson, 2009: The 2004-2008 mean and annual cycle of temperature, salinity, and steric height in the global ocean from the Argo Program. Prog. Oceanogr., 82, 81-100, https://doi.org/10.1016/j.pocean.2009.03.004.

, and - 2017: Roemmich-Gilson Argo climatology. Scripps Institution of Oceanography. Subset used: January
2004-December 2016, accessed 31 March 2017, http://sio-argo. ucsd.edu/RG_Climatology.html.

Schneider, N., A. J. Miller, M. A. Alexander, and C. Deser, 1999a: Subduction of decadal North Pacific temperature anomalies: Observations and dynamics. J. Phys. Oceanogr., 29, 1056-1070, https:// doi.org/10.1175/1520-0485(1999)029<1056:SODNPT>2.0.CO;2.

—, S. Venzke, A. J. Miller, D. W. Pierce, T. P. Barnett, C. Deser, and M. Latif, 1999b: Pacific thermocline bridge revisited. Geophys. Res. Lett., 26, 1329-1332, https://doi.org/10.1029/ 1999GL900222.

TAO Project Office, 2000: Tropical Atmosphere Ocean/Triangle Trans-Ocean Buoy Network. NOAA/PMEL, accessed 21 July 2016, https://www.pmel.noaa.gov/tao/drupal/disdel/.

Thomas, M. D., and A. V. Fedorov, 2017: The eastern subtropical Pacific origin of the equatorial cold bias in climate models: A Lagrangian perspective. J. Climate, 30, 5885-5900, https://doi.org/ 10.1175/JCLI-D-16-0819.1.

Toole, J. M., E. Zou, and R. C. Millard, 1988: On the circulation of the upper waters in the western equatorial Pacific Ocean. Deep-Sea Res., 35, 1451-1482, https://doi.org/10.1016/ 0198-0149(88)90097-0.

Tsuchiya, M., R. Lukas, R. A. Fine, E. Firing, and E. Lindstrom, 1989: Source waters of the Pacific Equatorial Undercurrent. Prog. Oceanogr., 23, 101-147, https://doi.org/10.1016/ 0079-6611(89)90012-8.

Zhang, D., and M. J. McPhaden, 2006: Decadal variability of the shallow Pacific meridional overturning circulation: Relation to tropical sea surface temperatures in observations and climate change models. Ocean Modell., 15, 250-273, https://doi.org/ 10.1016/j.ocemod.2005.12.005. 